\title{
GMR
}

\section{Contribution of morphoagronomic traits to grain yield and earliness in grain sorghum}

\author{
K.J. da Silva ${ }^{1}$, P.E. Teodoro ${ }^{2}$, C.B. de Menezes $^{3}$, M.P.M. Júlio ${ }^{4}$, \\ V.F. de Souza ${ }^{5}$, M.J. da Silva ${ }^{2}$, L.D. Pimentel ${ }^{1}$ and A. Borém ${ }^{1}$ \\ ${ }^{1}$ Departamento de Fitotecnia, Universidade Federal de Viçosa, \\ Viçosa, MG, Brasil \\ ${ }^{2}$ Departamento de Biologia Geral, Universidade Federal de Viçosa, \\ Viçosa, MG, Brasil \\ ${ }^{3}$ Núcleo de Desenvolvimento de Cultivares, Embrapa Milho e Sorgo, \\ Sinop, MT, Brasil \\ ${ }^{4}$ Departamento de Ciência Agrárias, \\ Universidade Federal de São João del-Rei, Sete Lagoas, MG, Brasil \\ ${ }^{5}$ Departamento de Engenharia de Biossistemas, \\ Universidade Federal de São João del-Rei, São João Del Rei, MG, Brasil \\ Corresponding author: P.E. Teodoro \\ E-mail: eduteodoro@hotmail.com
}

Genet. Mol. Res. 16 (2): gmr16029649

Received February 16, 2017

Accepted March 20, 2017

Published May 4, 2017

DOI http://dx.doi.org/10.4238/gmr16029649

Copyright $(2017$ The Authors. This is an open-access article distributed under the terms of the Creative Commons Attribution ShareAlike (CC BY-SA) 4.0 License.

\begin{abstract}
Given the importance of selecting lines to obtain hybrids, we aimed to verify the relationship between morphological traits that can be used as the criteria for the selection of sorghum lines with high grain yield and earliness. A total of 18 traits were evaluated in 160 sorghum elite lines, in an incomplete block design with two replicates. A correlation network was used to graphically express the estimates of phenotypic and genotypic correlations between the traits. Two path analyses were processed, the first considering grain yield and the second considering flowering as the principle dependent variable. In general, most of the variation in the grain yield and flowering of
\end{abstract}

Genetics and Molecular Research 16 (2): gmr16029649 
sorghum lines was explained by the traits evaluated. Selecting sorghum lines with greater width of the third leaf blade from flag leaf, panicle weight, and panicle harvest index might lead to increased grain yield, and selecting sorghum genotypes with higher plant height might lead to reduced earliness and increased grain yield. Thus, the results suggest the establishment of selection indices aiming at simultaneously increasing the grain yield and earliness in sorghum genotypes.

Key words: Sorghum bicolor; Path analysis; Indirect selection

\section{INTRODUCTION}

Sorghum [Sorghum bicolor (L.) Moench] is an African grass, which has a wide genetic diversity, being used for various purposes such as grain, silage, biomass, sugar, and broom. Over the natural evolution process, sorghum plants developed adaptation mechanisms for different environmental conditions, resulting in a wide genetic variation for tolerance to several stresses (Magalhães et al., 2012). These characteristics make this species cultivated in the second harvest in several regions of Brazil, especially in the Midwest and Triângulo Mineiro.

Several traits are evaluated in sorghum breeding programs, which ensure efficiency in the selection of lines for obtaining hybrids. Among the most relevant traits are the grain yield and earliness. Earlier genotypes offer greater security during the second harvest, the environment at that time being marked by water insufficiency. Thus, it is appropriate for that the plant to remain under unfavorable conditions for the shortest time possible. Other explored traits include tolerance to water deficit, absence of tannin in grains, height between 1.0 and $1.5 \mathrm{~m}$, resistance to predominant diseases in the planting area, environmental stability, and responsiveness to environmental improvements. (Silva et al., 2009; Tardin et al., 2013).

The understanding of the correlation between the characteristics under study at the initial stages of a breeding program is of great importance, especially in cases where the characteristic of interest exhibits low heritability and is difficult to measure (Rios et al., 2012). Assessing the direct and indirect effects is dependent on the traits set under study, which is usually established by the researcher's previous knowledge and possible interrelationships expressed in path diagrams (Cruz et al., 2014). Path analysis proposed by Wright (1921) allows the unfolding of the phenotypic correlations into direct and indirect effects of the traits on a principal variable, presenting greater reliability in the choice of selection traits.

In breeding programs, the knowledge of the direct and indirect effects of the explanatory variables on a principal trait might help in deciding on to use a correlated response or progress in selection (Rios et al., 2012). Despite the importance of this analysis, studies that used path analysis in sorghum are scarce. Thus, we aimed to verify the morphoagronomic traits that could be used as the selection criteria for grain sorghum lines with high grain yield and earliness.

\section{MATERIAL AND METHODS}

\section{Field trial}

We evaluated 160 sorghum elite lines, which are a part of the breeding program of

Genetics and Molecular Research 16 (2): gmr16029649 
Embrapa Maize and Sorghum. The trial was conducted in Sete Lagoas, the central region of Minas Gerais, located at latitude south $19^{\circ} 27^{\prime} 57^{\prime \prime}$ and longitude west $44^{\circ} 14^{\prime} 49^{\prime \prime}$ having an altitude tropical climate with hot and rainy summers and dry winters. The experimental plots consisted of 5-m long rows, spaced $0.50 \mathrm{~m}$ apart, in an incomplete block design with two replications.

\section{Traits evaluated}

Morphoagronomic traits were evaluated according to the minimum descriptors of sorghum proposed by the Ministry of Agriculture, Livestock and Food Supply, Brazil (1997):

1. Width of the third leaf blade from the flag leaf in $\mathrm{cm}(\mathrm{WL})$

2. Length of the third leaf blade from the flag leaf in $\mathrm{cm}$ (LL)

3. Shape and extension of the peduncle (SEP): visible above the flag leaf, measured at physiological maturity, in $\mathrm{cm}$, between the ligula of the flag leaf and the base of the panicle

4. Stem diameter (SD): measured at 15 to $20 \mathrm{~cm}$ from the ground

5. Stem quality (SQ): insipid below $8^{\circ}$ brix, sweet above $8^{\circ}$ brix

6 . Length of the main panicle rachis (LMPR): measured from the base of the panicle to the apex of the rachis

7. Length of the primary branch of the panicle (LPBP)

8. Anthracnose (Colletotrichum sublineolum) (ANT)

9. Helminthosporiosis (Exserohilum turcicum) (HEL)

10. Rust (Puccinia purpurea) (RUS)

Assessment of disease severity was measured using the rating scale adapted by Santos et al. (2005), where: $0=$ healthy plant, $1=$ less than $1 \%$ of the affected leaf area, $3=1$ to $5 \%$ of the affected leaf area, $5=6$ to $25 \%$ of the affected leaf area, $7=26$ to $50 \%$ of the affected leaf area, $9=$ more than $50 \%$ of the affected leaf area.

11. Plant height (PH): the length between the lap and the apex of the panicle measured at physiological maturity

12. Flowering (FLO): number of days from planting to flowering of $50 \%$ of the plants of the experimental unit

13. Number of plants per experimental plot (STA)

14. Moisture of grains (MOIG)

15. Panicle weight (PW): weight of all panicles of the experimental plot

16. Grain yield (YIE): the grains of the plot were harvested and subsequently measured for their moisture, and later adjusted to $13 \%$ moisture

17. Weight of thousand grains, in grams, adjusted to $13 \%$ moisture (WTG)

18. Panicle harvest index (PHI): ratio between grain weight and panicle weight

\section{Statistical analysis}

Initially, analysis of variance (ANOVA) was carried out for each trait, according to the statistical model described in Equation 1:

$$
Y_{i j}=\mu+B_{j}+G_{i}+e_{i j}
$$

Genetics and Molecular Research 16 (2): gmr16029649 
where Yij is the observation in the $\mathrm{j}$-th block evaluated in the $\mathrm{i}$-th genotype; $\mu$ is the overall mean of the experiment; $\mathrm{Bj}$ is the fixed effect of the $\mathrm{j}$-th block; $\mathrm{Gi}$ is the random effect of the $\mathrm{i}$-th genotype; eij is the random error associated with the Yij observation. Phenotypic $\left(\mathrm{r}_{\mathrm{F}}\right)$ and genotypic $\left(\mathrm{r}_{\mathrm{G}}\right)$ correlations between pairs of traits were estimated according to Equations 2 and 3, respectively:

$$
\begin{aligned}
& \mathrm{r}_{\mathrm{F}}=\frac{\mathrm{COV}_{\mathrm{F}(\mathrm{xy})}}{\sqrt{\hat{\sigma}_{\mathrm{Fx}}^{2} \times \hat{\sigma}_{\mathrm{Fy}}^{2}}} \\
& \mathrm{r}_{\mathrm{G}}=\frac{\mathrm{COV}_{\mathrm{G}(\mathrm{xy})}}{\sqrt{\hat{\sigma}_{\mathrm{Gx}}^{2} \times \hat{\sigma}_{\mathrm{Gy}}^{2}}}
\end{aligned}
$$

where in: $\operatorname{COV}_{\mathrm{F}(\mathrm{xy})}$ is the phenotypic covariance between traits $\mathrm{X}$ and $\mathrm{Y} ; \hat{\sigma}_{\mathrm{Fx}}^{2}$ is the phenotypic variance of trait $\mathrm{X}$; $\hat{\sigma}_{\mathrm{Fy}}^{2}$ is the phenotypic variance of trait $\mathrm{Y}$;; $\operatorname{COV}_{\mathrm{G}(\mathrm{xy})} \mathrm{e}$ is the genotypic covariance between traits $\mathrm{X}$ and $\mathrm{Y}$; $\hat{\sigma}_{\mathrm{Gx}}^{2}$ is the genotypic variance of trait $\mathrm{X}$; and $\hat{\sigma}_{\mathrm{Gy}}^{2}$ is the genotypic variance of trait Y.

In order to graphically express the functional relationship between the estimates of phenotypic and genotypic correlations between the traits, we used a correlation network in which the proximity between nodes (traces) was proportional to the absolute value of the correlation between these nodes. The thickness of the edges was controlled by applying a cut-off value of 0.50 , which meant that only $\left|\mathrm{r}_{\mathrm{ij}}\right| \geq 0.50$ had their edges highlighted. Finally, the positive correlations were represented in green, whereas the negative correlations were represented in red.

Subsequently, two path analyses were carried out: the first considering YIE as the principal dependent variable $(\mathrm{Y})$ and the second considering the FLO as the principal dependent variable $(\mathrm{Y})$, considering the model described in Equation 4:

$$
Y=p_{1} X_{1}+p_{2} X_{2}+\ldots+p_{n} X_{n}+p_{e} u
$$

where in $\mathrm{Y}$ is the principal dependent variable (YIE or FLO); $\mathrm{X}_{1}, \mathrm{X}_{2}, \ldots$, $\mathrm{xn}$ are the independent explanatory variables; $\mathrm{p}_{1}, \mathrm{p}_{2}, \ldots, \mathrm{p}_{\mathrm{n}}$ are the path analysis coefficients. The coefficient of determination $\left(\mathrm{R}^{2}\right)$ was calculated by Equation 5:

$$
R^{2}=p_{1 y}{ }^{2}+p_{2 y}{ }^{2}+\ldots 2 p_{2 y} p_{2 n} r_{2 n}
$$

(Equation 5)

The degree of multicollinearity of the $\mathrm{X}^{\prime} \mathrm{X}$ matrix was established based on its number of conditions (NC), which is the ratio between the largest and the smallest eigenvalue of the matrix (Montgomery et al., 2001). If $\mathrm{NC}<100$, the multicollinearity is considered weak and is not a problem for analysis; if $100 \leq \mathrm{NC} \leq 1,000$, the multicollinearity is considered moderate to strong; and if $\mathrm{NC}>1,000$ the multicollinearity is considered severe. All statistical analyses were carried out with the GENES software (Cruz, 2013).

Genetics and Molecular Research 16 (2): gmr16029649 


\section{RESULTS AND DISCUSSION}

\section{Analysis of variance and genetic parameters}

The F-test showed a significant effect $(\mathrm{p}<0.01)$ between the lines for all traits, allowing us to infer the existence of genetic variability in the population (Table 1). The experimental coefficient $\left(\mathrm{CV}_{\mathrm{e}}\right)$ was above $30 \%$ for the traits SEP, SQ, ANT, HELM, RUS, PW, and YIE, revealing the need for a greater number of replications (blocks) to increase the experimental accuracy of these traits.

Table 1. Summary of the joint analysis of variance for the traits evaluated in 160 grain sorghum in Sete Lagoas, 2015.

\begin{tabular}{l|c|c|c|c|c|c}
\hline Trait & $\mathrm{CV}_{\mathrm{e}}(\%)$ & $\mathrm{CV}_{\mathrm{g}}(\%)$ & $\mathrm{CV}_{\mathrm{r}}$ & $\mathrm{h}^{2}(\%)$ & Mean & $\mathrm{P}$ value \\
\hline WL & 14.88 & 11.62 & 0.78 & 54.93 & 7.07 & $<0.01$ \\
\hline LL & 8.66 & 9.36 & 1.08 & 70.02 & 60.56 & $<0.01$ \\
\hline SEP & 45.13 & 33.64 & 0.75 & 52.64 & 9.52 & $<0.01$ \\
\hline SD & 19.36 & 13.17 & 0.68 & 48.06 & 18.11 & $<0.01$ \\
\hline SQ & 36.76 & 21.21 & 0.58 & 39.96 & 8.78 & $<0.01$ \\
\hline LMPR & 24.44 & 12.44 & 0.97 & 65.37 & 7.06 & $<0.01$ \\
\hline LPBP & 29.81 & 19.13 & 0.78 & 55.07 & 2.48 & $<0.01$ \\
\hline ANT & 35.98 & 18.16 & 0.61 & 42.61 & 2.34 & $<0.01$ \\
\hline HELM & 31.71 & 28.71 & 0.80 & 56.00 & 1.19 & $<0.01$ \\
\hline RUS & 33.85 & 22.40 & 0.66 & 46.68 & 1.84 & $<0.01$ \\
\hline PH & 6.39 & 26.53 & 4.15 & 97.18 & 109.35 & $<0.01$ \\
\hline FLO & 6.66 & 5.54 & 0.83 & 58.05 & 75.95 & $<0.01$ \\
\hline STA & 21.12 & 16.82 & 0.80 & 55.94 & 32.42 & $<0.01$ \\
\hline MOIG & 10.09 & 6.57 & 0.65 & 45.87 & 12.56 & $<0.01$ \\
\hline PW & 56.64 & 47.70 & 0.84 & 58.65 & 854.83 & $<0.01$ \\
\hline YIE & 41.14 & 54.28 & 1.32 & 77.69 & 2757.95 & $<0.01$ \\
\hline WTG & 24.24 & 14.77 & 0.61 & 42.62 & 17.01 & $<0.01$ \\
\hline PHI & 19.97 & 18.80 & 0.94 & 63.94 & 0.56 & $<0.01$ \\
\hline
\end{tabular}

WL: width of the third leaf blade from the flag leaf; LF: length of the third leaf blade from the flag leaf; SEP: shape and extension of the peduncle; SD: stem diameter; SQ: stem quality; LMPR: length of the main panicle rachis; LPBP: length of the primary branch of the panicle; ANT: anthracnose (Colletotrichum sublineolum); HEL: helminthosporiosis (Exserohilum turcicum); RUS: rust (Puccinia purpurea); PH: plant height; FLO: flowering; STA: number of plants per experimental plot; MOIG: moisture of grains; PW: panicle weight; YIE: grain yield; WTG: weight of thousand grains; PHI: panicle harvest index; $\mathrm{CV}_{\mathrm{e}}$ : experimental coefficient; $\mathrm{CV}_{\mathrm{g}}$ : coefficient of genetic variation; $\mathrm{CV}_{\mathrm{r}}$ : relative coefficient of variation.

The coefficient of genetic variation $\left(\mathrm{CV}_{\mathrm{g}}\right)$ quantifies the proportion of genetic variability available for selection (Cruz et al., 2014). The ratio between $\mathrm{CV}_{\mathrm{g}}$ and $\mathrm{CV}_{\mathrm{e}}$ results in the relative coefficient of variation $\left(\mathrm{CV}_{\mathrm{r}}\right)$. Thus, the values obtained for $\mathrm{CV}_{\mathrm{g}}$ enabled $\mathrm{CV}_{\mathrm{r}}$ $>1$ and high heritability estimates $\left(\mathrm{h}^{2}>70 \%\right)$ for the traits LL, PH, and YIE. These results revealed promising situations for the selection of superior lines with decreased $\mathrm{PH}$ decreased and increased YIE, which are the main objectives of the sorghum breeding program.

\section{Phenotypic and genotypic correlations}

There were positive and significant phenotypic correlations $(\mathrm{p}<0.01)$ between the traits LMPR x LPBP (0.5883), PH x PW (0.5793), PH x YIE (0.5845), PW x YIE (0.7011), and WTG $x$ PHI (0.6192). These results initially indicated that PH and PW can be used as the selection criteria for sorghum lines with high YIE. However, to use these traits as the indirect selection criteria, it is necessary to verify if there is a cause and effect relationship between them.

Genetics and Molecular Research 16 (2): gmr16029649 
In order to clarify the phenotypic interrelationships between various morphoagronomic traits evaluated in this study, a two-dimensional correlation network was used to detect complex phenotypic patterns, which were difficult to assess with other techniques (Figure 1). In the correlation network, the values of significant correlations by t-test were highlighted with bold edges, where negative correlations were expressed in the red-colored lines and positive correlations in the green-colored lines. The efficiency of this innovative technique has been reported by Ursem et al. (2008), DiLeo et al. (2011) and Silva et al. (2016).

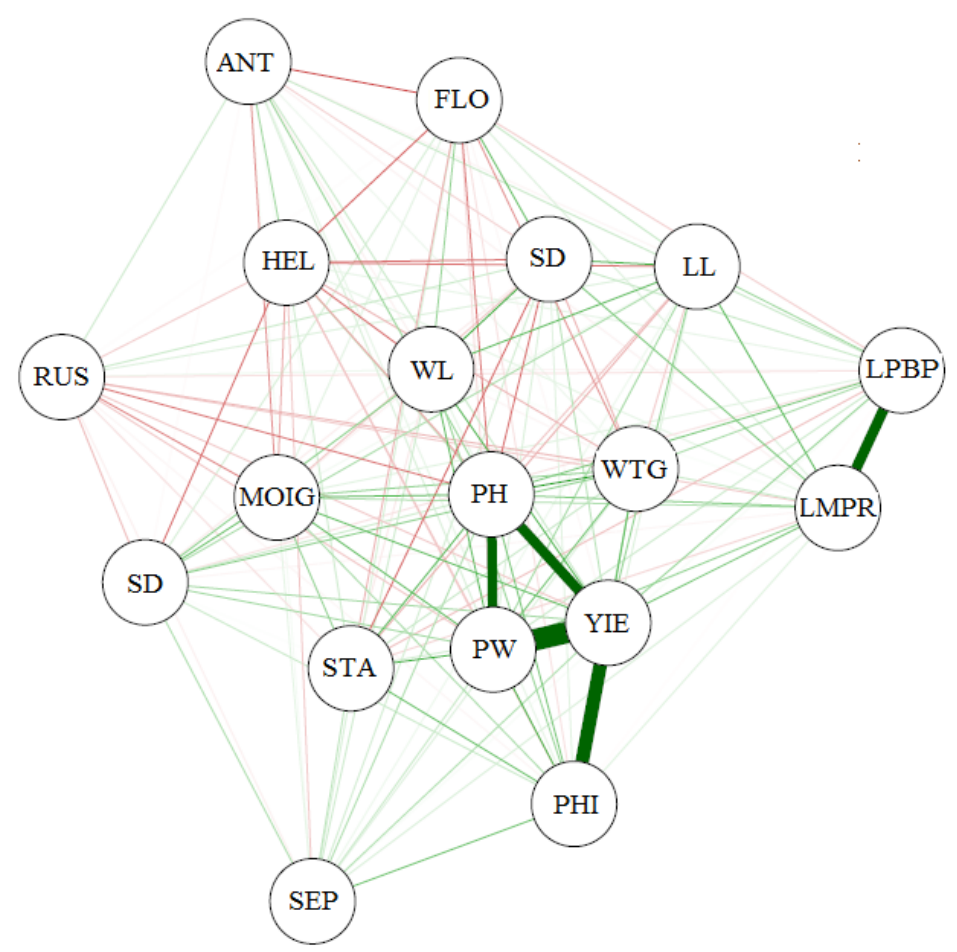

Figure 1. Phenotypic correlation network among traits evaluated in 160 grain sorghum lines.

However, for the indirect selection to be efficient, one of the assumptions is that a genetic correlation should exist between the traits used. Therefore, we estimated the genotypic correlations, which showed a positive and significant association $(\mathrm{p}<0.01)$ between the traits SD x WL (0.6749), SD x LL (0.6219), SD x FLO (0.5189), WL x PW (0.5465), WL x YIE (0.5399), SQ x MOIG (0.6840), SQ x WTG (0.6237), LMPR x LPBP (0.7009), PH x MOIG (0.5243), PH x PW (0.7424), PH x YIE (0.6632), PH x WTG (0.7317), PW x YIE (0.9374), STA x PW (0.5232), MOIG x YIE (0.5176), MOIG x WTG (0.5022), PHI x PW (0.7235), and PHI x YIE (0.7794). These results are in accordance with those reported by Sandeep et al. (2011), Rani and Umakanth (2012), and Lombardi et al. (2015).

In general, it is possible to verify an interrelationship between the morphoagronomic traits, and some of them have a genotypic correlation with YIE. If this association is translated into a cause-and-effect relationship, the traits, such as PH, PW, and PHI, could be used as 
the indirect selection criteria, especially for the greater ease of measurement. A negative and significant association $(\mathrm{p}<0.01)$ was found to exist between the traits HELM x WL $(-0.5613)$, HELM x SD (-0.5130), HELM x FLO (-0.5246), and ANTR x FLO (-0.7364). These results showed that the sorghum plants susceptible to diseases, such as HELM and ANTR, reduced their photosynthetic leaf area and, consequently, their life cycles.

Genotypic correlations showed the same sign and, in most cases, values higher than their corresponding phenotypic correlations, indicating that the genotypic expression of these traits was decreased by environmental influences. The main causes of genotype correlation between two traits are pleiotropism, a property by which a gene conditions more than one trait simultaneously, and linkage disequilibrium, a non-random association between the alleles from different loci (Cruz et al., 2014). Therefore, a genotypic correlation network was built to facilitate the interpretation of genotypic relationships between the traits (Figure 2).

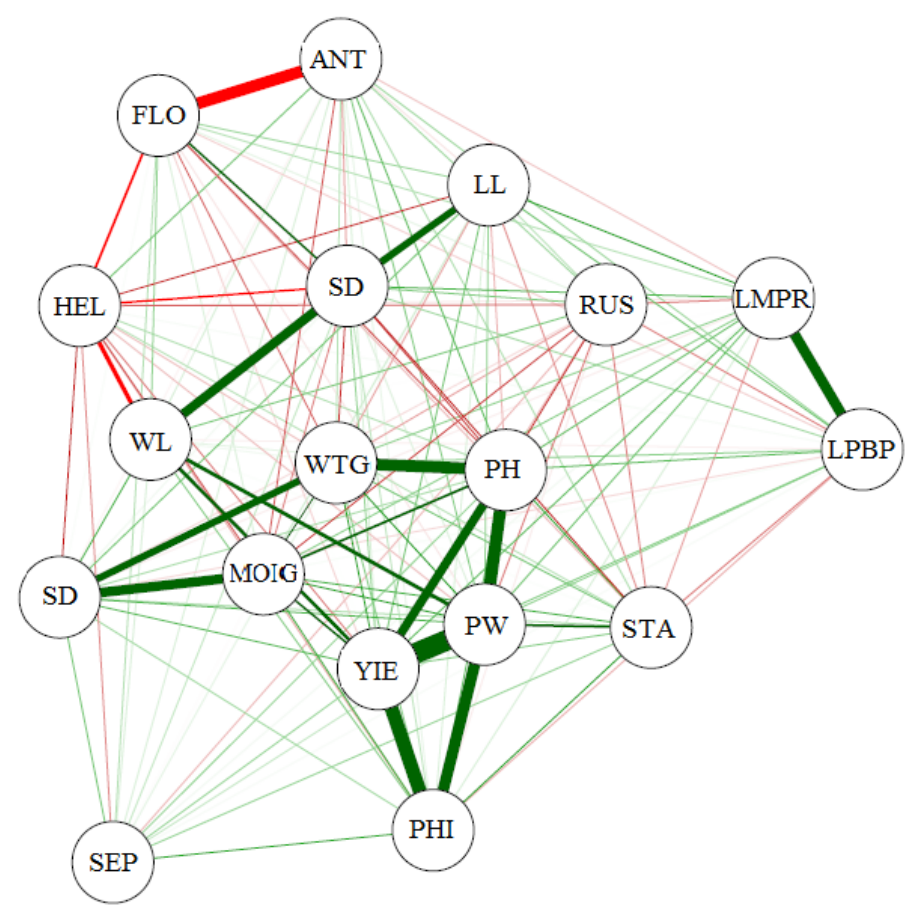

Figure 2. Genotypic correlation network among traits evaluated in 160 grain sorghum lines.

However, despite the importance of phenotypic and genotypic correlation coefficients, their interpretation can lead to misconceptions regarding the relation between two traits, and might not be a true measure of cause and effect. A high or low correlation coefficient between two traits might be the result of an effect that a third trait or a group of traits have on the pair, not giving the exact relative importance to the direct and indirect effects of these factors (Toebe and Cargnelutti Filho, 2013). Therefore, we proceeded to the path analysis, which investigates the relationship of cause and effect. Cruz et al. (2014) mentions that path analysis provides a detailed knowledge of the influences of the traits involved, and justify the existence of positive and negative correlations of high and low magnitude among the traits studied.

Genetics and Molecular Research 16 (2): gmr16029649 
Phenotypic correlation has genetic and environmental causes, but only the genetic ones involve an association of inheritable nature that can be used to guide breeding programs. Therefore, we used the matrix of genotypic correlations between traits for path analysis, as recommended by Teixeira et al. (2012) and Azevedo et al. (2016).

However, to obtain the direct and indirect effects of path analysis, it is necessary that the X'X matrix be well conditioned. Under the presence of multicollinearity, the variances associated with the path coefficient estimators can reach exceedingly high values, making them unreliable. In addition, the parameter estimates might assume absurd values or show no coherence with the studied biological phenomenon (Cruz et al., 2014). According to the criteria described by Montgomery et al. (2001), the grain yield (Table 2) and flowering (Table 3 ) were analyzed in sorghum lineages in this way by adding a constant $(\mathrm{K})$ on the principal diagonal of the $\mathrm{X}^{\prime} \mathrm{X}$ matrix before performing each path analysis. The $\mathrm{k}$ value of 0.20 was the lowest value that provided stabilization of the direct effects in the two path analyses.

Table 2. Estimates of the direct and indirect effects of independent explanatory variables on the principal dependent variable (YIE) in 160 grain sorghum in Sete Lagoas, 2015.

\begin{tabular}{|c|c|c|c|c|c|c|c|c|c|c|c|c|c|c|c|c|c|}
\hline Effect & $\mathrm{WL}$ & LL & SEP & SD & SQ & LMPR & LPBP & ANT & HELM & RUS & $\mathrm{PH}$ & FLO & STA & MOIG & PW & WTG & PHI \\
\hline Direct on YIE & 0.303 & 0.132 & 0.028 & -0.045 & -0.137 & -0.069 & 0.113 & 0.001 & 0.136 & 0.055 & 0.190 & 0.102 & -0.210 & 0.260 & 0.276 & 0.110 & 0.404 \\
\hline Indirect via WL & & 0.100 & 0.022 & 0.205 & 0.110 & 0.001 & -0.009 & 0.022 & -0.170 & 0.078 & 0.014 & 0.066 & 0.002 & -0.002 & 0.166 & 0.008 & 0.070 \\
\hline Indirect via LL & 0.043 & & 0.001 & 0.082 & 0.035 & 0.059 & 0.038 & -0.006 & -0.055 & 0.017 & -0.020 & 0.025 & -0.029 & 0.012 & 0.027 & -0.023 & 0.009 \\
\hline Indirect via SEP & 0.002 & 0.000 & & 0.003 & 0.008 & 0.001 & 0.000 & 0.002 & -0.007 & -0.004 & 0.006 & 0.004 & 0.006 & 0.000 & 0.003 & 0.001 & 0.012 \\
\hline Indirect via SD & -0.031 & -0.028 & -0.005 & & -0.001 & -0.016 & -0.008 & 0.009 & 0.023 & -0.011 & 0.017 & -0.024 & 0.021 & 0.011 & -0.003 & 0.019 & -0.006 \\
\hline Indirect via SQ & -0.049 & -0.036 & $\begin{array}{l}-0.037 \\
-0.037 \\
\end{array}$ & -0.003 & & 0.004 & 0.010 & 0.003 & 0.064 & 0.009 & -0.022 & -0.001 & $\frac{-0.022}{-0.022}$ & -0.093 & $\begin{array}{r}-0.049 \\
-0.049\end{array}$ & -0.085 & -0.024 \\
\hline Indirect via LMPR & 0.000 & -0.031 & -0.002 & -0.025 & 0.002 & & -0.048 & 0.008 & 0.003 & 0.019 & -0.020 & -0.010 & 0.013 & -0.015 & -0.019 & -0.015 & -0.005 \\
\hline Indirect via LPBP & -0.003 & 0.032 & 0.002 & 0.020 & -0.008 & 0.080 & & 0.021 & 0.002 & -0.028 & 0.037 & -0.010 & -0.029 & 0.001 & 0.024 & 0.026 & -0.017 \\
\hline Indirect via ANT & 0.000 & 0.000 & 0.000 & 0.000 & 0.000 & 0.000 & 0.000 & & 0.000 & 0.000 & 0.000 & -0.001 & 0.000 & 0.000 & 0.000 & 0.000 & 0.000 \\
\hline Indirect via HELM & -0.076 & -0.057 & -0.032 & -0.070 & -0.064 & -0.006 & 0.002 & 0.036 & & -0.041 & 0.020 & -0.071 & 0.018 & -0.046 & -0.017 & -0.016 & -0.022 \\
\hline Indirect & 0.014 & 0.007 & -0.007 & 0.013 & -0.004 & -0.015 & -0.014 & 0.0 & -0.0 & & -0.024 & 0.0 & -0.014 & -0.021 & -0.014 & -0.010 & -0.002 \\
\hline Indirect via PH & 0.009 & -0.029 & 0.037 & -0.072 & 0.031 & 0.056 & 0.063 & 0. & 0.02 & -0.0 & & -0.068 & 0.077 & 0.10 & 0.141 & 0.139 & 0.059 \\
\hline Indirect via FLO & 0.022 & 0.019 & 0.015 & 0.053 & 0.001 & 0.014 & -0.009 & -0.075 & $\begin{array}{r}-0.0263 \\
\end{array}$ & 0.005 & -0.036 & & -0.013 & 0.006 & $\begin{array}{r}0.141 \\
-0.005 \\
\end{array}$ & $\frac{0.1370}{-0.030}$ & $\begin{array}{r}-0.008 \\
-0.008\end{array}$ \\
\hline Indirect via STA & -0.001 & 0.046 & -0.042 & 0.096 & -0.033 & 0.038 & 0.054 & -0.031 & $\begin{array}{l}-0.053 \\
-0.027\end{array}$ & 0.052 & -0.085 & 0.028 & & -0.078 & -0.110 & -0.056 & -0.096 \\
\hline Indirect via MOIG & -0.001 & 0.023 & -0.001 & -0.063 & 0.178 & 0.058 & 0.003 & -0.086 & -0.088 & -0.098 & 0.136 & 0.016 & 0.097 & & 0.117 & 0.131 & 0.098 \\
\hline Indirect via PW & 0.151 & 0.057 & 0.029 & 0.01 & 0.099 & 0.075 & 0.059 & 0.067 & -0.034 & -0.072 & 0.205 & -0.012 & 0.144 & 0.124 & & 0.129 & 0.200 \\
\hline Indirect via WTG & 0.003 & -0.019 & 0.005 & -0.045 & 0.068 & 0.024 & 0.025 & 0.015 & -0.013 & -0.020 & 0.080 & -0.032 & 0.029 & 0.055 & 0.051 & & 0.026 \\
\hline Indirect via PHI & 0.094 & 0.028 & 0.173 & 0.050 & 0.070 & 0.028 & -0.061 & 0.017 & -0.067 & -0.015 & 0.126 & -0.033 & 0.185 & 0.152 & 0.292 & 0.097 & \\
\hline Total Correlation & 0.540 & 0.269 & 0.193 & 0.207 & 0.328 & 0.316 & 0241 & 0.071 & -0.248 & -0.123 & 0.663 & 0.002 & 0.233 & 0.518 & 0.937 & 0.446 & 0.779 \\
\hline
\end{tabular}

WL: width of the third leaf blade from the flag leaf; LF: length of the third leaf blade from the flag leaf; SEP: shape and extension of the peduncle; SD: stem diameter; SQ: stem quality; LMPR: length of the main panicle rachis; LPBP: length of the primary branch of the panicle; ANT: anthracnose (Colletotrichum sublineolum); HEL: helminthosporiosis (Exserohilum turcicum); RUS: rust (Puccinia purpurea); PH: plant height; FLO: flowering; STA: number of plants per experimental plot; MOIG: moisture of grains; PW: panicle weight; YIE: grain yield; WTG: weight of thousand grains; PHI: panicle harvest index.

When YIE was considered as the basic variable, the traits WL, PW, and PHI showed the greatest positive direct effect. These traits also presented the genotype correlations of moderate-to-high magnitude with YIE, indicating a cause and effect relationship between them. Therefore, due to their greater ease of measurement, these traits can be used to select more productive genotypes in grain sorghum breeding programs, especially when evaluating YIE becomes impossible.

When FLO was considered as the basic variable, the traits PW, SEP, SD, and MOIG showed the highest direct positive effects, while the traits PHI, PH, and SQ showed the greatest direct negative effects. However, the traits SEP, SQ, and PHI presented a null or lowmagnitude correlation with the FLO trait, indicating that these directs effects were the results of the indirect effects from the other traits such as SD and PH. Therefore, SD and PH are the most recommended traits to be used as the indirect selection criteria in grain sorghum breeding programs, which aim at the earliness of genotypes for growing in the Brazilian Cerrado.

Genetics and Molecular Research 16 (2): gmr16029649 
Table 3. Estimates of the direct and indirect effects of independent explanatory variables on the principal dependent variable (FLO) in 160 grain sorghum in Sete Lagoas, 2015.

\begin{tabular}{|c|c|c|c|c|c|c|c|c|c|c|c|c|c|c|c|c|c|}
\hline Effect & $\mathrm{WL}$ & LL & SEP & SD & SQ & LMPR & LPBP & ANT & HELM & RUS & $\mathrm{PH}$ & STA & MOIG & $\mathrm{PW}$ & YIE & WTG & PHI \\
\hline Direct on FLO & $\frac{W L}{-0.310}$ & $\frac{L L}{-0.111}$ & $\begin{array}{ll}\mathrm{SLT} \\
0.597\end{array}$ & $\frac{S D}{0.541}$ & $\frac{S Q}{-0.675}$ & $\frac{-0.094}{-0.154}$ & $\begin{array}{l}\frac{L I D T}{-0.212} \\
-\end{array}$ & -0.395 & $\frac{1}{-0.136}$ & 0.136 & $\frac{11}{-0.803}$ & $\begin{array}{l}1 \mathrm{~A} \\
0.014\end{array}$ & 0.510 & 0.997 & $\frac{1 \mathrm{~L}}{0.131}$ & 0.389 & -0.916 \\
\hline Indirect via WL & & -0.102 & -0.023 & -0.209 & -0.112 & -0.001 & 0.009 & -0.022 & 0.174 & -0.079 & -0.015 & -0.002 & 0.002 & -0.169 & -0.167 & -0.008 & -0.072 \\
\hline Indirect via LL & -0.037 & & 0.000 & -0.069 & -0.030 & -0.050 & -0.032 & 0.005 & 0.047 & -0.014 & 0.017 & 0.024 & -0.010 & -0.023 & -0.030 & 0.019 & -0.008 \\
\hline Indirect via SEP & 0.044 & 0.002 & & 0.065 & 0.161 & 0.013 & 0.009 & 0.041 & -0.139 & -0.079 & 0.117 & 0.119 & -0.003 & 0.063 & 0.115 & 0.027 & 0.255 \\
\hline Indirect via SD & 0.365 & 0.337 & 0.059 & & 0.013 & 0.197 & 0.097 & -0.108 & -0.278 & 0.130 & -0.204 & -0.247 & -0.130 & 0.033 & 0.112 & -0.221 & 0.067 \\
\hline Indirect via SQ & -0.244 & -0.180 & -0.182 & -0.016 & & 0.021 & 0.049 & 0.013 & 0.318 & 0.043 & -0.109 & -0.107 & -0.461 & -0.242 & -0.221 & -0.421 & -0.116 \\
\hline Indir & 0.000 & -0.042 & -0.002 & -0.034 & 0.003 & & -0.066 & 0.01 & 0.00 & 0.026 & -0.027 & 0.0 & -0.021 & -0.026 & -0.030 & -0.020 & -0.006 \\
\hline $\begin{array}{l}\text { Indirect via LPBP } \\
\text { a }\end{array}$ & 0.006 & -0.061 & -0.003 & -0.038 & 0.015 & -0.148 & & -0.039 & -0.003 & 0.052 & -0.070 & 0.055 & -0.002 & -0.045 & -0.051 & -0.048 & 0.032 \\
\hline Indirect via ANT & -0.028 & 0.018 & -0.027 & 0.079 & 0.007 & 0.043 & -0.072 & & -0.106 & -0.071 & -0.123 & -0.058 & 0.131 & -0.096 & -0.028 & -0.054 & -0.017 \\
\hline Indirect via HELM & 0.076 & 0.057 & 0.032 & 0.070 & 0.064 & 0.006 & -0.002 & -0.036 & & 0.041 & -0.020 & -0.018 & 0.046 & 0.017 & 0.034 & 0.016 & 0.022 \\
\hline Indirect via RUS & 0.035 & 0.017 & -0.018 & 0.033 & -0.009 & -0.038 & -0.033 & 0.024 & -0.042 & & -0.058 & -0.034 & -0.051 & -0.036 & -0.017 & -0.025 & -0.005 \\
\hline Indir & -0.038 & 0.122 & -0.158 & 0.303 & -0.130 & -0.235 & -0.265 & -0.249 & -0.118 & 0. & & -0.326 & -0.421 & -0.596 & -0.533 & -0.588 & -0.250 \\
\hline Indirec & 000 & -0.003 & 0.003 & -0.006 & 0.002 & -0.003 & -0.004 & 0.00 & 0.0 & -0.003 & 0.006 & & 0.005 & 0.007 & 0.003 & 0.004 & 0.006 \\
\hline Indirect via MOIG & -0.003 & 0.045 & -0.002 & -0.123 & 0.349 & 0.114 & 0.006 & $\begin{array}{c}0.002 \\
-0.169 \\
\end{array}$ & -0.172 & -0.192 & 0.267 & 0.190 & & 0.229 & 0.264 & 0.256 & 0.192 \\
\hline Indirect via P & 0.545 & 0.206 & 0.105 & 0.06 & 0.358 & 0.2 & 0.2 & 0.2 & & -0.259 & 0.7 & 0.5 & 0.448 & & 0.934 & & 0.721 \\
\hline Indirec & 0.071 & 0.035 & 0.025 & 0.027 & 0.043 & 0.041 & 0.032 & 0.009 & -0.032 & -0.016 & 0.087 & 0.030 & 0.068 & 0.123 & & 0.058 & 0.102 \\
\hline Indirect & 0.010 & $\frac{-0.068}{-0.068}-1$ & 0.017 & $\frac{0.027}{-0.159}$ & 0.043 & 0.084 & 0.089 & 0.053 & $\begin{array}{l}-0.052 \\
-0.047\end{array}$ & $\begin{array}{ll}-0.071 \\
-0.071\end{array}$ & 0.285 & 0.104 & 0.195 & 0.182 & 0.174 & & 0.1093 \\
\hline Indirect & -0.212 & -0.063 & -0.392 & -0.113 & -0.158 & -0.06 & 0.139 & -0.039 & 0.151 & 0.033 & -0.285 & -0.419 & -0.344 & -0.662 & -0.714 & -0.220 & \\
\hline direct via TOTAL & 0.218 & 0.188 & 0.150 & 0.519 & 0.010 & 0.140 & -0.087 & -0.736 & -0.525 & 0.045 & $\begin{array}{l}-0.356 \\
\end{array}$ & $\begin{array}{c}-0.132 \\
\end{array}$ & 0.062 & -0.045 & 0.002 & $\begin{array}{l}-0.290 \\
-0.290\end{array}$ & 0.081 \\
\hline
\end{tabular}

WL: width of the third leaf blade from the flag leaf; LF: length of the third leaf blade from the flag leaf; SEP: shape and extension of the peduncle; SD: stem diameter; SQ: stem quality; LMPR: length of the main panicle rachis; LPBP: length of the primary branch of the panicle; ANT: anthracnose (Colletotrichum sublineolum); HEL: helminthosporiosis (Exserohilum turcicum); RUS: rust (Puccinia purpurea); PH: plant height; FLO: flowering; STA: number of plants per experimental plot; MOIG: moisture of grains; PW: panicle weight; YIE: grain yield; WTG: weight of thousand grains; PHI: panicle harvest index.

However, these results should be interpreted with caution, since it would be necessary to decrease SD and select sorghum lines with PH between 1 and $1.5 \mathrm{~m}$ (Santos, 2003) in order to select earlier sorghum genotypes, making the plants more susceptible to bedding. The $\mathrm{PH}$ trait also exerted a direct effect of moderate magnitude on the YIE trait, indicating that it is also determines the yield of the evaluated population. In addition to this, $\mathrm{PH}$ has a high accuracy in its evaluation (low $\mathrm{CV}_{\mathrm{e}}$ ), high heritability and ease of measurement, promising situations for indirect selection. Thus, the selection of taller genotypes can be efficient to reduce the cycle and increase grain yield. However, if the breeder does not intend to increase PH, restricted selection indices should be used.

Coefficient of determination obtained for path analysis was 0.95 with YIE as the main variable (model 1) and 0.88 with FLO as the main variable (model 2). These values were higher than the residual variable effect in each model $(0.22$ for the first and 0.34 for the second), indicating that most of the variation in grain yield and flowering of sorghum lines was explained by the traits evaluated. At last, the results reported in this study allow for the establishment of selection indices, which aim at simultaneously increasing the grain yield and earliness in sorghum genotypes.

Therefore, selecting sorghum genotypes with a greater WL, PW, and PHI could increase the grain yield. Selecting sorghum genotypes with higher PH can reduce earliness and increase YIE. These strategies will serve to guide the intermediate stages of selection in sorghum breeding programs. For future researches, these traits can be used in the establishment of selection indices to identify sorghum genotypes that meet the precocity and have high grain yield.

\section{Conflicts of interest}

The authors declare no conflict of interest.

Genetics and Molecular Research 16 (2): gmr16029649 


\section{ACKNOWLEDGMENTS}

We thank Coordenação de Aperfeiçoamento de Pessoal de Nível Superior (CAPES), and Conselho Nacional de Desenvolvimento Científico e Tecnológico (CNPq) for financial support.

\section{REFERENCES}

Azevedo AM, Seus R, Gomes CL, Freitas EM, et al. (2016). Correlações genotípicas e análise de trilha em famílias de meios-irmãos de couve de folhas. Pesqui. Agropecu. Bras. 51: 35-44. http://dx.doi.org/10.1590/S0100204X2016000100005

Cruz CD (2013). GENES - a software package for analysis in experimental statistics and quantitative genetics. Acta Sci. Agron. 35: 271-276. http://dx.doi.org/10.4025/actasciagron.v35i3.21251

Cruz CD, Carneiro PCS and Regazzi AJ (2014). Modelos biométricos aplicados ao Melhoramento Genético. 3rd edn. Editora UFV, Viçosa.

DiLeo MV, Strahan GD, den Bakker M and Hoekenga OA (2011). Weighted correlation network analysis (WGCNA) applied to the tomato fruit metabolome. PLoS One 6: e26683. http://dx.doi.org/10.1371/journal.pone.0026683

Lombardi GMR, Nunes JAR, Parrella RAC, Teixeira DHL, et al. (2015). Path analysis of agro-industrial traits in sweet sorghum. Genet. Mol. Res. 14: 16392-16402. http://dx.doi.org/10.4238/2015.December.9.8

Magalhães PC, Souza TC and Rodrigues JAS (2012). Ecofisiologia. In: Rodrigues JAS (Ed.). Cultivo do sorgo. Sete Lagoas: Embrapa Milho e Sorgo.

Ministry of Agriculture, Livestock and Food Supply, Brazil (1997). Instruções para execução dos ensaios de Distinguibilidade, Homogeneidade e Estabilidade de cultivares de sorgo (Sorghum bicolor). Diário Oficial da União.

Montgomery DC, Peck EA and Vining GG (2001). Introduction to linear regression analysis, 3 ed. John Wiley \& Sons, New York.

Rani C and Umakanth AV (2012). Genetic variation and trait inter-relationship in F1 hybrids of sweet sorghum (Sorghum bicolor (L.) Moench). J. Trop. Agric. 50: 80-83.

Rios AS, Borem A, Guimarães PEO and Paes MCD (2012). Análise de trilha para carotenoides em milho. Rev. Ceres 59: 368-373. http://dx.doi.org/10.1590/S0034-737X2012000300011

Sandeep RG, Rao MRG, Bhat BV, Kulkarni RS, et al. (2011). Inter-relationship between sugar yield and its component characters in two segregating populations of sweet sorghum. Electron. J. Plant Breed 2: 244-247.

Santos FG (2003). Cultivares de Sorgo. Sete Lagoas: Embrapa Milho e Sorgo.

Santos GR, Café-Filho AC, Leão FF, César M, et al. (2005) Progresso do crestamento gomoso e perdas na cultura da melancia. Horticult. Bras. 23: 228-232.

Silva AG, Barros AS, Silva LHCP, Morães EB, et al. (2009). Avaliação de cultivares de sorgo granífero na safrinha no sudoeste do Estado de Goiás. Pesqui. Agropecu. Trop. 39: 168-174.

Silva AR, Rêgo ER, Pessoa AMS and Rêgo MM (2016). Correlation network analysis between phenotypic and genotypic traits of chili pepper. Pesqui. Agropecu. Bras. 51: 372-377. http://dx.doi.org/10.1590/S0100-204X2016000400010

Tardin DD, Almeida Filho JE, Oliveira CM and Leite CEP (2013). Avaliação agronômica de híbridos de sorgo granífero cultivados sob irrigação e estresse hídrico. Rev. Bras. Milho Sorgo 12: 102-117. http://dx.doi.org/10.18512/19806477/rbms.v12n2p102-117

Teixeira DHL, Oliveira MSP, Gonçalves FMA and Nunes JAR (2012). Correlações genéticas e análise de trilha para componentes da produção de frutos de açaizeiro. Rev. Bras. Frutic. 34: 1135-1142. http://dx.doi.org/10.1590/S010029452012000400022

Toebe M and Cargnelutti Filho A (2013). Não normalidade multivariada e multicolinearidade na análise de trilha em milho. Pesqui. Agropecu. Bras. 48: 466-477. http://dx.doi.org/10.1590/S0100-204X2013000500002

Ursem R, Tikunov Y, Bovy A, Berloo R van et al. (2008). A correlation network approach to metabolic data analysis for tomato fruits. Euphytica 161: 181-193. http://dx.doi.org/10.1007/s10681-008-9672-y

Wright S (1921). Correlation and causation. J. Agric. Res. 20: 557-585.

Genetics and Molecular Research 16 (2): gmr16029649 